\title{
Effect of Irrigation Schedule and Amino Acids Biostimulants on Soil Enzyme Activities in Potato (Solanum tuberosum L.) Crop
}

\author{
Vimal Kumar ${ }^{1 *}$, Priyankar Raha ${ }^{1}$ and Shankar Ram ${ }^{2}$ \\ ${ }^{1}$ Department of Soil Science \& Agricultural Chemistry, Institute of Agricultural Sciences, \\ Banaras Hindu University, Varanasi-221005, India \\ ${ }^{2}$ Soil and Land use survey of India, GOI, Noida Centre, Uttar Pradesh, India \\ *Corresponding author
}

\section{A B S T R A C T}

\begin{tabular}{|c|}
\hline Keywords \\
\hline $\begin{array}{l}\text { Potato crop, Irrigation } \\
\text { schedule, Soil enzyme } \\
\text { activities, Amino acid } \\
\text { biostimulants }\end{array}$ \\
\hline Article Info \\
\hline $\begin{array}{l}\text { Accepted: } \\
16 \text { March } 2018 \\
\text { Available Online: } \\
10 \text { April } 2018\end{array}$ \\
\hline
\end{tabular}

The field experiment was conducted alluvial soil of Indo-Gangatic plain at the Institute of Agricultural Research Farm, Banaras Hindu University, Varanasi, Uttar Pradesh, India. The experiment of potato crop was laid out in a split-plot design with three irrigation schedules $\left(I_{1}, I_{2}\right.$ and $\left.I_{3}\right)$ and four amino acid based biostimulants $\left(A_{0}, A_{1}, A_{2}\right.$ and $\left.A_{3}\right)$ and after harvested soil sample analysis soil enzyme activities. The effect of irrigation on enzyme activities dehydrogenase, protease and alkaline phosphatase was observed nonsignificant and effect of amino acid based biostimulants was significant. In the interaction effect of irrigation and amino acid based biostimulants on enzyme activities best performance observed in dehydrogenase activities $\mathrm{I}_{3} \mathrm{~A}_{2}$ in first experiment and second experiment $\mathrm{I}_{2} \mathrm{~A}_{2}$. Protease activities was observed highest in $\mathrm{I}_{2} \mathrm{~A}_{2}$ both the experiment and alkaline phosphatase activities was observed highest in $\mathrm{I}_{2} \mathrm{~A}_{2}$ in first experiment and $\mathrm{I}_{1} \mathrm{~A}_{2}$ in second experiment. All the interaction effect on enzyme activities was observed non significantly effect.

\section{Introduction}

Soil is a living system where all the biochemical activities proceed through enzymatic process (Kiss et al., 1975). Soil enzyme activity can be used as an indicator of soil quality for assessing the sustainability of agricultural ecosystems (Roldan et al., 2005). Soil enzymes play an essential role in the nutrient mineralization and their activity is an exceptional 'sensor' in predicting the capacity of nutrient supply to plants. They may correlate with nutrient availability (Asmar $e t$ al., 1994) in soil. Bacteria and fungi synthesize and secrete enzymes such as phosphatases, proteases and pectinases extracellular. Those microbial secreted enzymes constitute an important part of the soil matrix as extra-cellular enzymes, also called abiotic enzymes (Sinsabaugh, 1994). Factors influencing soil microbial activity exert control over soil enzyme production and control on nutrient availability and soil fertility (Sinsabaugh et al., 1994). In particular, phosphatase production and activity have been reported to be very sensitive to soil organic matter concentration (Goldstein et al., 1988). Phosphatases are involved in the 
transformation of organic and inorganic phosphorus compounds in soil (Amador et al., 1997) and their activities are an important factor in maintaining and controlling the rate of $\mathrm{P}$ cycling through soils. These released phosphorus in soil improved the $\mathrm{P}$ content in potato by enhancing $\mathrm{P}$ uptake by crop. On the other hand, the increase of protease activity by the application of amino acid biostimulant application may have positive effects on the activity of the others enzymes involving $\mathrm{N}$ cycles since it is one of the enzymes that break down labile polypeptide and other protein polymers. Thus, released $\mathrm{N}$ in the form $\mathrm{NH}_{4}{ }^{+}$ to $\mathrm{NO}_{3}{ }^{-}$enhanced the $\mathrm{N}$-content and protein content in potato.

Biological oxidation of organic compounds is generally a dehydrogenation process and there are many dehydrogenizes (enzyme catalyzing dehydrogenation), which are highly specific.

$$
\mathrm{XH}_{2}+\mathrm{A} \frac{\text { Dehydrogenase }}{\text { Oxidoreductase }} \mathrm{X}+\mathrm{AH}_{2}
$$

Where, $\mathrm{XH}_{2}$ is an organic compound (hydrogen donor) and $\mathrm{A}$ is a hydrogen accepter. The dehydrogenase enzyme systems apparently fulfill a significant role in oxidation of soil organic matter as they transfer $\mathrm{H}$ from subtracts to acceptors (Skujins, 1967).

Thus dehydrogenase enzyme activity enhancement in soil led to degradation of soil organic matter and release of $\mathrm{N}, \mathrm{P}$ and $\mathrm{S}$. The released $S$ in soil enhanced the uptake of $S$ by crop and content in tubers. Protein in plant and animal residues are hydrolyzed by protease enzyme. Enzyme protease attacks the protein molecule and hydrolyzes the peptide (-CO$\mathrm{NH}$ ) bonds and release free amino acids viz., peptones and peptides.

Proteins $\stackrel{\text { Protease }}{\longrightarrow}$ Peptones, Peptides $\stackrel{\text { Protease }}{\longrightarrow}$ Amino acids
Proteases play an important role in mineralization of soil nitrogen. They are involved in cleavage of proteins to polypeptides and oligopeptides to amino acids. The phosphatases are divided in to five group viz., phosphoric monoester hydrolases, phosphoric diester hydrolases, triphosphoric monoster hydrolases, anhydride acting enzymes, P-N phosphoamidases. General equation of the hydrolysis of organophosphorus compounds in soil. The phosphatase enzymes are classified as acid and alkaline phosphatases.

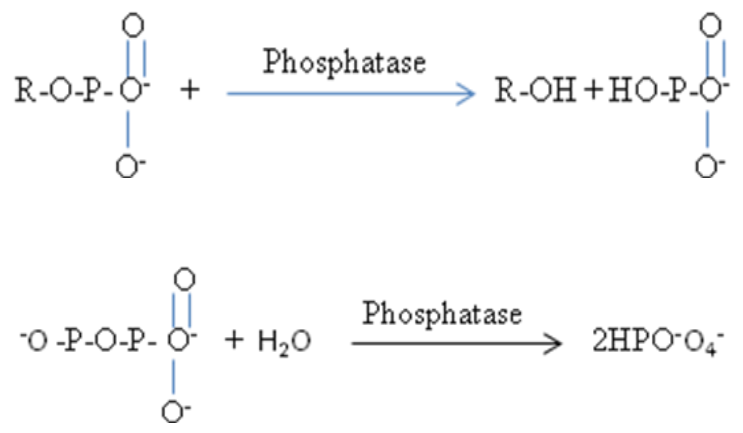

Amino acid $\mathrm{N}$ contents in soils (Chen et al., 2002) between $30-45 \%$ of the total N. It occurs mostly in soils as single compounds, peptides and proteins bound to clay minerals external and internal surfaces and to humic colloids by hydrogen and covalent bonds. Small amounts of free amino acids occur in the soil liquid phase.

They may originate during the conversion of protein $\mathrm{N}$ to $\mathrm{NH}_{3}$ by heterotrophic organisms, as excretory products of invertebrates, and secreted by microorganisms and plant roots. In general, the amino acid composition of soils shows great similarities to that of bacteria, thus indicating that most of the amino acids present (Schnitzer, 1991) in soil are of microbial origin. The activities of enzymes involved in the different nutrient cycles viz. dehydrogenase (S-cycle) protease $(\mathrm{N}$-cycle) phosphatase (P-cycle) were estimated after harvesting the field experiment of potato crop 
soil in different treatment combination of irrigation levels $\left(I_{1}, I_{2}\right.$ and $\left.I_{3}\right)$ and sources of amino acid $\left(\mathrm{A}_{1}, \mathrm{~A}_{2}\right.$ and $\left.\mathrm{A}_{3}\right)$ spraying during field experiment of potato crop.

\section{Materials and Methods}

\section{Experiment field site description}

The field experiment was conducted for two consecutive years (2014-15 and 2015-16) which is research farm situated at North - East plains Zone of the Eastern part of Uttar Pradesh at $25^{0} 18^{\prime}$ North Latitude $83^{0} 36^{\prime}$ East longitudes and at an altitude of 80.71 meters above mean sea level in the Gangatic plain of eastern Uttar Pradesh, India. The district Varanasi rainfalls in a semi-arid to sub-humid climate and means annual precipitation is $1100 \mathrm{~mm}$.

The area occasionally experiences winter cyclonic rain during December to February. In term of percentage of total rainfall, about $84 \%$ is received from June to September, 0.7\% October to December, 6\% from January to February and $9.3 \%$ from March to May as pre monsoon rain (Fig. 1).

The rainfall, relative humidity and wind speed high in first year cultivation period and temperature, sunshine and evaporation high in second year cultivation period.

\section{Experimental conditions}

The trial was laid out in a split-plot design with three irrigation schedules $\left(\mathrm{I}_{1}, \mathrm{I}_{2}\right.$ and $\left.\mathrm{I}_{3}\right)$ in main-plots and four amino acid based biostimulants $\left(A_{0}, A_{1}, A_{2}\right.$ and $\left.A_{3}\right)$ in sub-plots with three replications. The variety of potato (E-3797) tuber seeds was planted rabi season in the month of November at a spacing of 50 $\mathrm{cm}$ ridge to ridge and $20 \mathrm{~cm}$ plant to plant. The recommended dose of fertilizers for the crop was 150:100:120 NPK kg ha ${ }^{-1}$ at basal application of $1 / 2$ doses $\mathrm{N}+$ full dose of phosphorus + full dose of potash. The main plot treatment of irrigation schedule water applied at $\mathrm{I}_{1}$ (3 irrigation), $\mathrm{I}_{2}$ (4 irrigation) and $\mathrm{I}_{3}$ (5 irrigation). The sub-plot applied four types $\left(A_{0}, A_{1}, A_{2}\right.$ and $\left.A_{3}\right)$ of amino acid based biostimulants of $\left(\mathrm{A}_{0}\right)$ control, $\left(\mathrm{A}_{1)}\right.$ plant based, $\left(\mathrm{A}_{2}\right)$ animal based and $\left(\mathrm{A}_{3}\right)$ mixture amino acid at three application schedule of amino acid. The first application of amino acid based biostimulants at five leaves stage of the crop, second application at tuber initiation stage and third application at fifteen days after second stage of application. All the biostimulants are in liquid formulation $(250 \mathrm{~mL}$ of amino acid/100L of water, $\mathrm{ha}^{-1)}$ and will be applied through sprayer, mixing/diluting with water.

\section{Collection of soil sample}

Soil samples collected from field experiment of potato crop at after harvesting, stored at $4^{0} \mathrm{C}$ for analysis of assay enzyme activities. For the impact assessment of amino acid biostimulants under different irrigation schedule on soil enzyme activities, viz., dehydrogenase, protease and alkaline phosphatase were analyzed.

\section{Enzyme activities measurements}

\section{Dehydrogenase}

Dehydrogenase activity in the soil sample was estimated by (Casida et al., 1964) method.

\section{Protease}

Protease activity was determined by (Reysek et al., 2008) methods.

\section{Alkaline phosphatase}

Activity of alkaline phosphatase estimation in soil was described (Tabatabai and Bremner, 1969). 


\section{Enzyme activities cycle in soil}

Water availability plays a role in the performance of soil microbial communities in natural (Fig. 2) and agricultural ecosystems at the level of microbial growth, biomass (Fierer et al., 2003; Hueso et al., 2011; Hueso et al., 2012; Meisner et al., 2013) microbial composition and biogeochemical cycles (Placella et al., 2012; Goransson et al., 2012).

The low irrigation dose, increases the alkaline phosphatase activity were observed in the soils and at high irrigation, dehydrogenase activity was significantly decreased in commercial fertilized soil, relative to non-fertilized soil and pine bark, ash, and $\mathrm{N}$ (Moreno et al., 2017).

\section{Results and Discussion}

The enzyme activities in field experiment effect of irrigation on dehydrogenase activities was found highest in 4 irrigation schedule and decrease after 3 irrigation, 5 irrigation schedule respectively in first year experiment (Table 1) and the second year field experiment soil effect of irrigation on dehydrogenase activities was found highest activities in 3 irrigation schedule, 4 irrigation and 5 irrigation schedule respectively. The entire irrigation schedule both the year was found non- significant effect of dehydrogenase activities.

The enzyme activities of protease effect of irrigation was found highest in 3 irrigation schedule both the year of experiment and after decrease 4 irrigation, 5 irrigation schedule respectively both the year of experiment (Table 1). The activities of protease were found all the effect of irrigation schedule was non-significantly effect. The enzyme activities of dehydrogenase and protease was found second year highest than first year experiment and the time of cultivation period rain fall was found highest $(0.99 \mathrm{~mm})$ than second year rain fall $(0.30 \mathrm{~mm})$ in cultivation period. The effect of higher irrigation schedule decreases the activities of dehydrogenase and protease activates. The activity of alkaline phosphatase effect of irrigation was found highest in 4 irrigation schedule and after 5 irrigation and 3 irrigation schedules respectively (Table 1), in first year experiment soil and in second year activities highest in 3 irrigation schedule after 5 irrigation and 4 irrigation schedules respectively. All the effect of irrigation schedule was found non significantly effect of alkaline phosphatase in soil.

The soil enzyme activities, viz., dehydrogenase, protease and alkaline phosphatase were significantly increased in the harvested soil due to application of different sources of amino acids in potato crop.

Maximum activity (Fig. 3) of dehydrogenase (689.97 and 912.67 $\mathrm{\mu g} \mathrm{g}^{-1} \mathrm{TPF}_{\text {day }}{ }^{-1}$ soil), protease (8.31 $13.38 \mu \mathrm{g} \mathrm{L}$ - tyrosine $\mathrm{g}^{-1}$ soil h$^{-1}$ ) (Fig. 4) and alkaline phosphatase (Fig. 5) (43.19 and 33.30 $\mu \mathrm{g} \mathrm{PNPg}^{-1}$ soil $\mathrm{h}^{-1}$ ) in harvested soil were observed due to application of plant based amino acids $\left(\mathrm{A}_{2}\right)$ in both the year.

The enzyme activities of dehydrogenase and protease was found highest in second year than first year experiment at the time of cultivation period rain fall was observed highest $(0.99 \mathrm{~mm})$ than second year rain fall $(0.30 \mathrm{~mm})$ in cultivation period. Thus, overall the order of impact on enzyme activities in soil due to application of amino acids biostimulants was $A_{2}>A_{1}>A_{3}$. These results are same with many others reported in the literature, showing enhancement soil enzyme activities are correlated with biostimulant application (Chen et al., 2002; Chen, 2003). 
Fig.1 Meteorological data of Varanasi district during the cultivation period (November to March) of potato crop

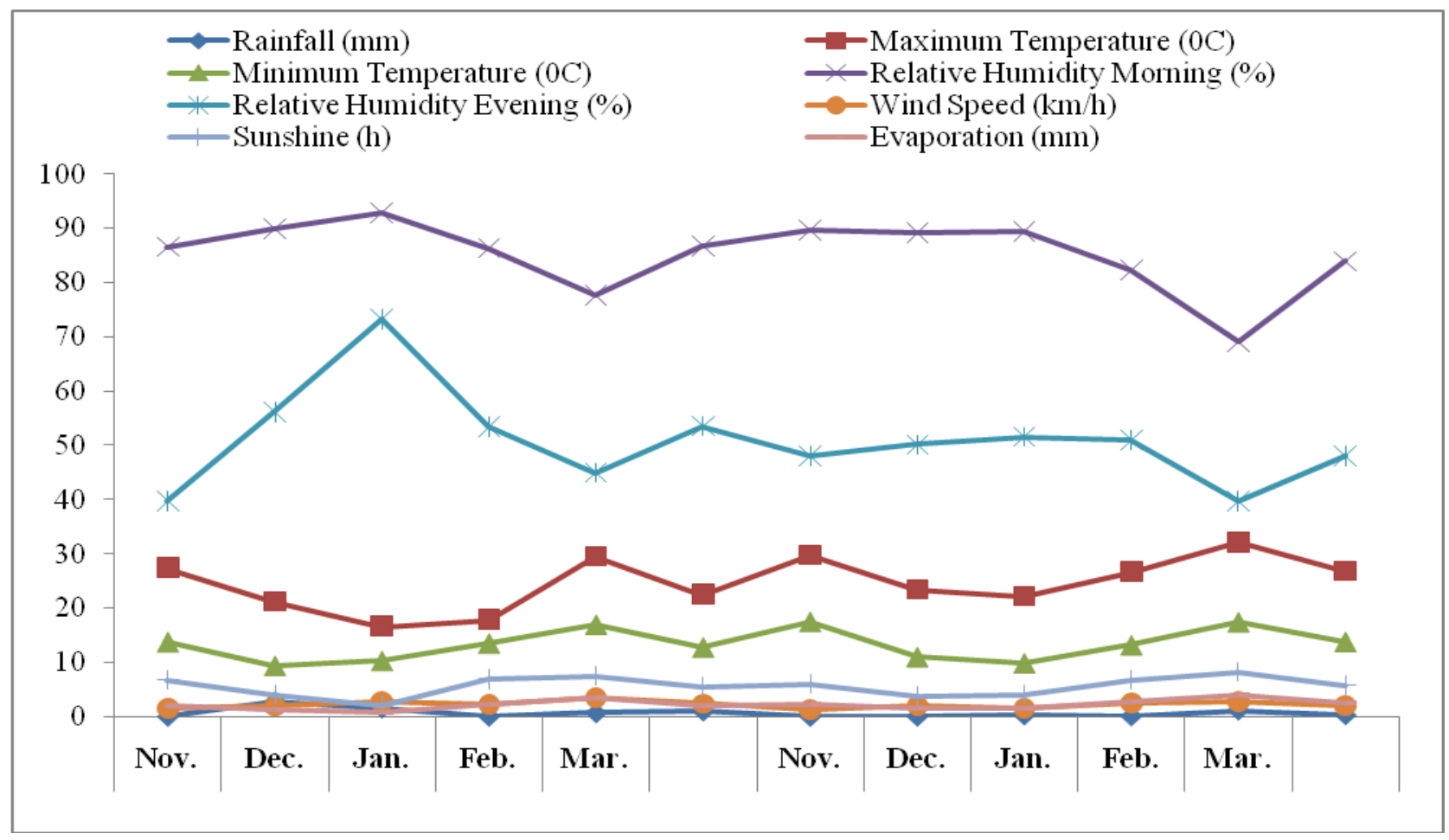

Fig.2 Effect of irrigation and amino acids based biostimulants on enzyme activities cycle in soil

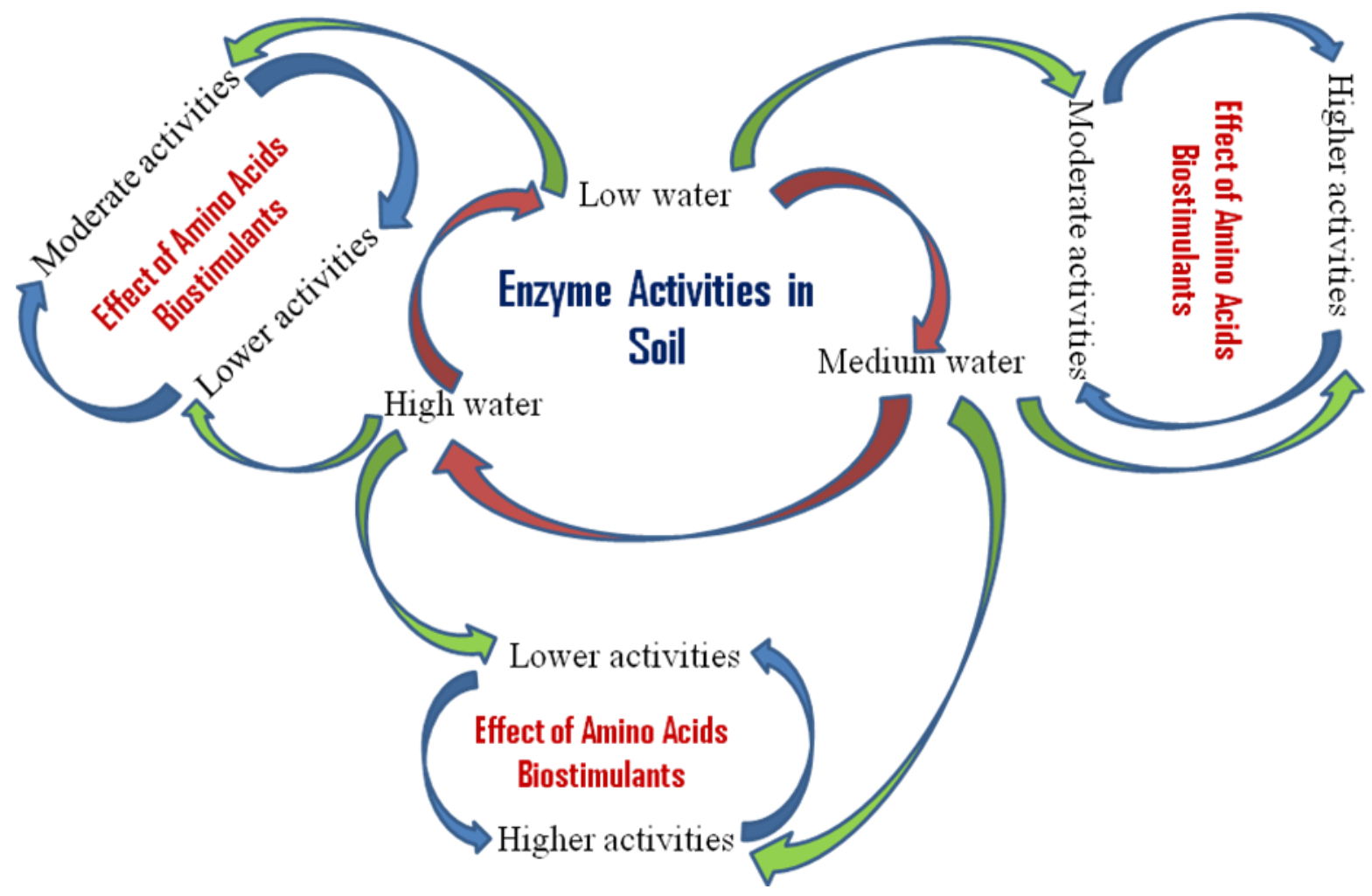


Fig.3 Effect of amino acids based biostimulants on dehydrogenase

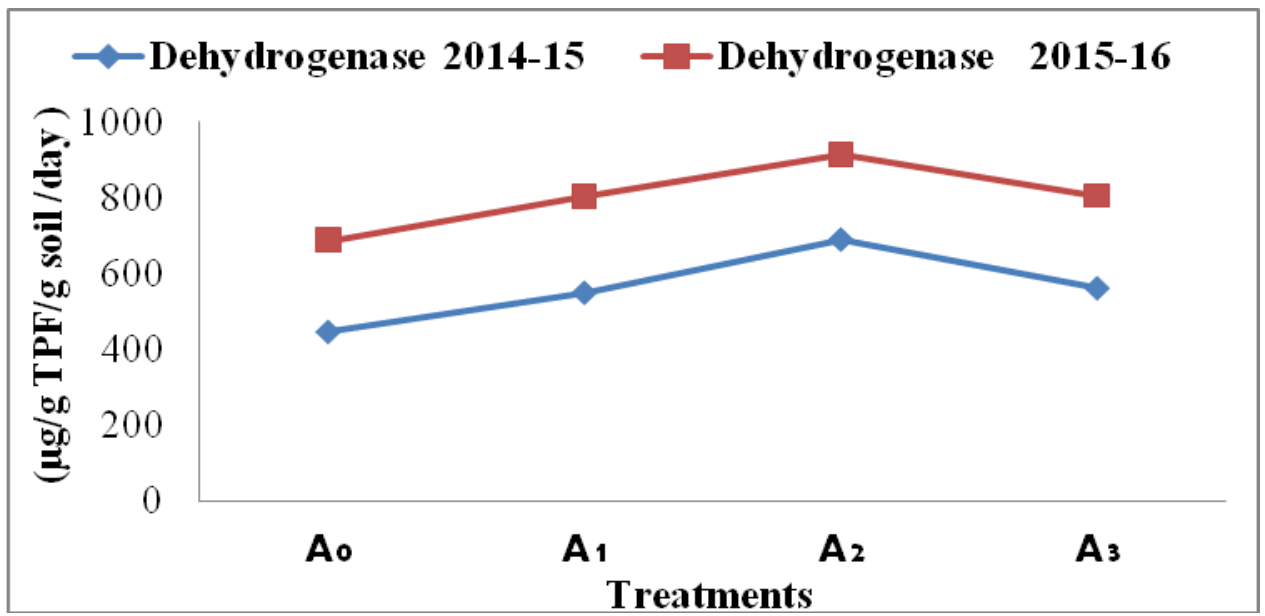

Fig.4 Effect of amino acids based biostimulants on protease activities

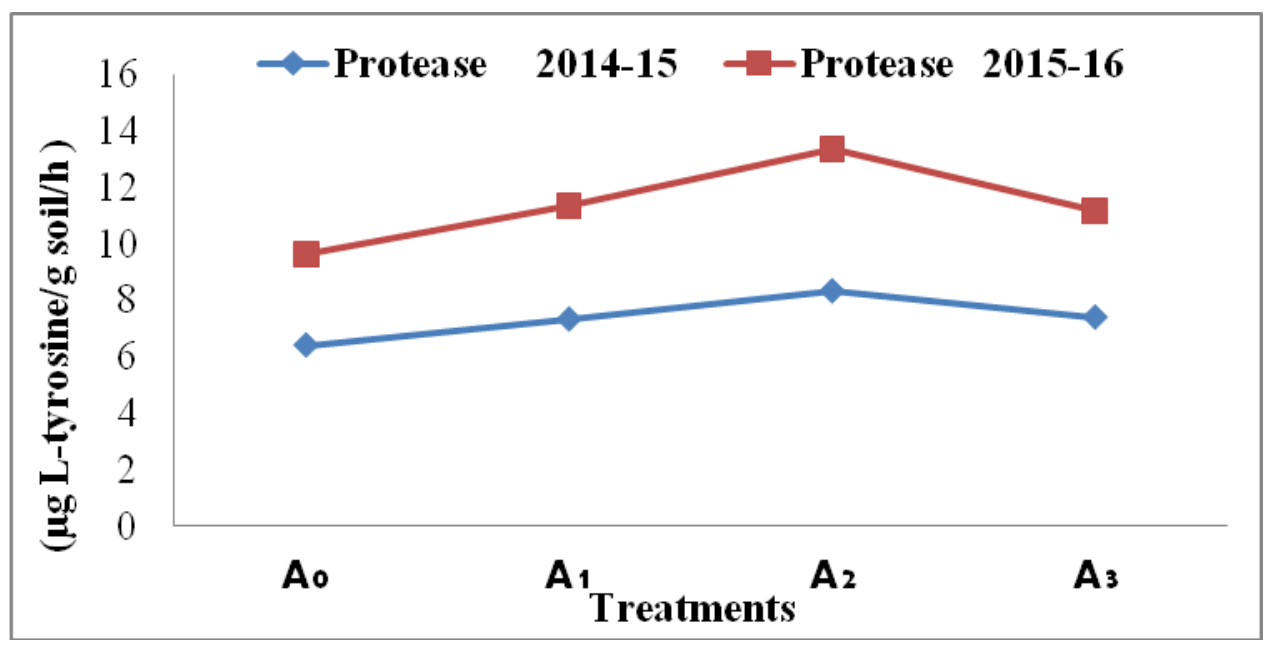

Fig.5 Effect of amino acids based biostimulants on alkaline phosphatase activities

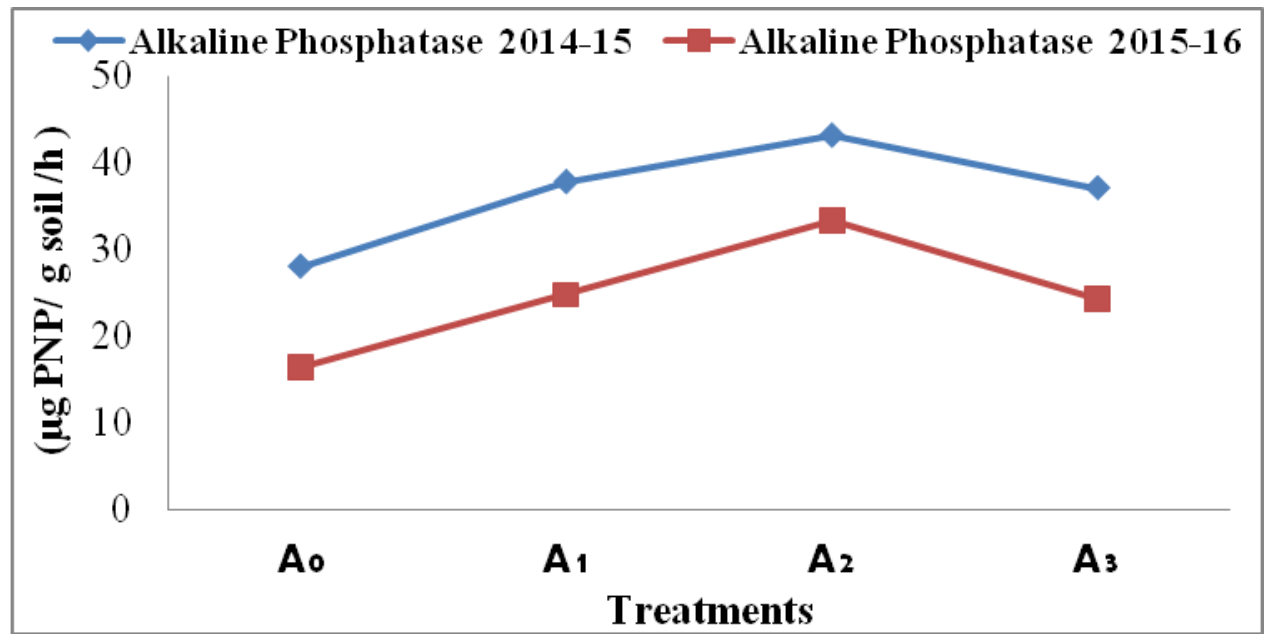


Table.1 Effect of irrigation on enzyme activities

\begin{tabular}{|c|c|c|c|c|c|c|}
\hline \multirow[t]{2}{*}{ Treatments } & \multicolumn{2}{|c|}{$\begin{array}{c}\text { Dehydrogenase } \\
\left(\mu \mathrm{g} \mathrm{g}^{-1} \mathrm{TPF}^{-1} \text { soil day }{ }^{-1)}\right.\end{array}$} & \multicolumn{2}{|c|}{$\begin{array}{c}\text { Protease } \\
\left(\mu \mathrm{g} \mathrm{L} \text {-tyrosine } \mathrm{g}^{-1} \text { soil }^{-1)}\right.\end{array}$} & \multicolumn{2}{|c|}{$\begin{array}{l}\text { Alkaline Phosphatase } \\
\left(\mu \mathrm{g} \text { PNP g }{ }^{-1} \text { soil h }^{-1)}\right.\end{array}$} \\
\hline & 2014-15 & 2015-16 & 2014-15 & $2015-16$ & 2014-15 & 2015-16 \\
\hline $\mathrm{I}_{1}$ & 551.02 & 836.72 & 7.41 & 11.79 & 34.44 & 28.13 \\
\hline $\mathrm{I}_{2}$ & 587.56 & 794.77 & 7.37 & 11.37 & 38.21 & 22.67 \\
\hline $\mathrm{I}_{3}$ & 546.66 & 771.62 & 7.26 & 11.03 & 36.95 & 23.24 \\
\hline SEm $( \pm)$ & NS & NS & NS & NS & NS & NS \\
\hline $\mathrm{CD}(\mathrm{P}=0.05)$ & NS & NS & NS & NS & NS & NS \\
\hline
\end{tabular}

Table.2 Interaction effect of irrigation and amino acids based biostimulants on enzyme activities of soil at the time of harvesting of experiment field

\begin{tabular}{|c|c|c|c|c|c|c|}
\hline \multirow[t]{2}{*}{ Treatments } & \multicolumn{2}{|c|}{$\begin{array}{c}\text { Dehydrogenase } \\
\left(\mu \mathrm{g} \mathrm{g}^{-1} \mathrm{TPF}^{-1} \text { soil day }^{-1)}\right.\end{array}$} & \multicolumn{2}{|c|}{$\begin{array}{c}\text { Protease } \\
\left(\mu \mathrm{g} \text { L-tyrosine } \mathrm{g}^{-1} \text { soil }^{-1)}\right.\end{array}$} & \multicolumn{2}{|c|}{$\begin{array}{l}\text { Alkaline Phosphatase } \\
\left(\mu \mathrm{g} \mathrm{PNP} \mathrm{g}^{-1} \text { soil }^{-1)}\right.\end{array}$} \\
\hline & 2014-15 & 2015-16 & 2014-15 & 2015-16 & 2014-15 & 2015-16 \\
\hline $\mathrm{I}_{1} \mathrm{~A}_{0}$ & 469.74 & 726.21 & 6.98 & 10.13 & 26.91 & 18.11 \\
\hline $\mathrm{I}_{1} \mathrm{~A}_{1}$ & 522.25 & 835.31 & 7.55 & 11.82 & 37.09 & 27.28 \\
\hline $\mathrm{I}_{1} \mathrm{~A}_{2}$ & 672.59 & 910.84 & 7.6 & 13.64 & 42.99 & 42.11 \\
\hline $\mathrm{I}_{1} \mathrm{~A}_{3}$ & 539.49 & 874.52 & 7.51 & 11.58 & 30.76 & 25.03 \\
\hline $\mathrm{I}_{2} \mathrm{~A}_{0}$ & 491.79 & 684.31 & 6.17 & 9.08 & 29.52 & 17.92 \\
\hline $\mathrm{I}_{2} \mathrm{~A}_{1}$ & 572.13 & 780.95 & 7.23 & 11.93 & 38.7 & 23.82 \\
\hline $\mathrm{I}_{2} \mathrm{~A}_{2}$ & 678.94 & 941.79 & 9.03 & 13.91 & 44.74 & 24.19 \\
\hline $\mathrm{I}_{2} \mathrm{~A}_{3}$ & 607.37 & 772.03 & 7.03 & 10.55 & 39.89 & 24.75 \\
\hline $\mathrm{I}_{3} \mathrm{~A}_{0}$ & 377.01 & 648.08 & 6.01 & 9.70 & 27.61 & 13.21 \\
\hline $\mathrm{I}_{3} \mathrm{~A}_{1}$ & 553.99 & 788.95 & 7.14 & 10.36 & 37.67 & 23.25 \\
\hline $\mathrm{I}_{3} \mathrm{~A}_{2}$ & 718.38 & 885.07 & 8.28 & 12.59 & 41.84 & 33.60 \\
\hline $\mathrm{I}_{3} \mathrm{~A}_{3}$ & 537.27 & 764.37 & 7.6 & 11.48 & 40.68 & 22.90 \\
\hline SEm \pm & NS & NS & NS & NS & NS & NS \\
\hline $\mathrm{CD}=0.05)$ & NS & NS & NS & NS & NS & NS \\
\hline
\end{tabular}


In the interaction effect of irrigation and amino acid based biostimulants on enzyme activity with 5 irrigation schedule and plant based amino acid biostimulants $\left(\mathrm{I}_{3} \mathrm{~A}_{2}\right)$ was best performance $(718.38, \mu \mathrm{g} / \mathrm{g}$ TPF /g soil /day) dehydrogenase activities in first year experiment and second year $\left(\mathrm{I}_{2} \mathrm{~A}_{2}\right) 4$ irrigation schedule and plant based amino acid biostimulants ( $941.79 \mu \mathrm{g} / \mathrm{g}$ TPF /g soil /day) in (Table 2). The effect of irrigation and amino acid based biostimulants on Protease activities was observed highest in 4 irrigation schedule and plant based amino acid biostimulants $\left(\mathrm{I}_{2} \mathrm{~A}_{2}\right)$ both the year of experiment and alkaline phosphatase activities was observed highest in $\left(\mathrm{I}_{2} \mathrm{~A}_{2}\right) 4$ irrigation schedule and plant based amino acid biostimulants (44.74, $\mu \mathrm{g}$ PNP/g soil $/ \mathrm{h})$ in first year and $\left(\mathrm{I}_{1} \mathrm{~A}_{2}\right) 3$ irrigation schedule and plant based amino acid biostimulants (42.11, $\mu \mathrm{g}$ PNP/ $\mathrm{g}$ soil $/ \mathrm{h}$ ) in second year experiment. All the interaction effect of irrigation and amino acid based biostimulants on enzyme activities dehydrogenase, protease and alkaline phosphatase was observed nonsignificant effect.

In the cultivation period effect of climatic condition in first year- rainfall $(0.99 \mathrm{~mm})$, temperature (maximum $22.52{ }^{\circ} \mathrm{C}$ and minimum $12.79{ }^{0} \mathrm{C}$ ), relative humidity (morning $86.58 \%$ and evening $53.60 \%)$, wind speed $\left(2.37 \mathrm{~km} \mathrm{~h}^{-1}\right)$ sunshine $(5.47 \mathrm{~h})$ and evaporation $(1.98 \mathrm{~mm})$ and second year climatic condition-rainfall $(0.30 \mathrm{~mm})$, temperature (maximum $26.83{ }^{0} \mathrm{C}$ and minimum $13.80{ }^{\circ} \mathrm{C}$ ), relative humidity (morning $83.83 \%$ and evening $48.14 \%$ ), wind speed $\left(2.01 \mathrm{~km} \mathrm{~h}^{-1}\right)$ sunshine $(5.76 \mathrm{~h})$ and evaporation $(2.36 \mathrm{~mm})$ was observed climatic variability on dehydrogenase and protease activities, over all dehydrogenase and protease activities interaction highest in second year experiment than first year experiment and the alkaline phosphatase activities over all interaction highest in first year experiment than second year experiment.

The different levels of irrigation schedules $\left(\mathrm{I}_{1}\right.$, $I_{2}$ and $I_{3}$ ) during crop cultivation were non significantly influenced the enzyme activities (viz. dehydrogenase, protease and alkaline phosphate) in both years of cultivation after harvesting the soil. The soil enzymes related to protein transformation (protease), organic phosphorus transformation (alkaline phosphatase) and organic matter decomposition (dehydrogenase) activities greatly improved by the spraying of plant based $\left(\mathrm{A}_{2}\right)$, animal source $\left(\mathrm{A}_{1)}\right.$ and mixtured amino acids $\left(\mathrm{A}_{3}\right)$ on crops. The soil enzyme activities (dehydrogenase, protease and alkaline phosphatase) were significantly enhanced by the spraying of all the amino acid based biostimulants on crop and the order of overall impact of soil enzyme activities in soil due to application of amino acids biostimulants was $\mathrm{A}_{2}>\mathrm{A}_{1}>\mathrm{A}_{3}$. Thus, amino acids application improved the soil health plant growth and development.

\section{References}

Amador, J.A., Glucksman, A.M., Lyons, J.B. and Gorres, J.H. (1997) Spatial distribution of soil phosphatase activity within a riparian forest. Soil Science, 162, 808-825.

Asmar, F., Eiland, F. and Nielsen, N.E., (1994) Effect of extracellular-enzyme activities on solubilization rate of soil organic nitrogen. Biology and Fertility of Soils, 17, 32-38.

Casida, L. E., Jn. Klein, D. L. and Santaro, T. (1964) Soil dehydrogenase activity. Soil Science, 96, 371-376.

Chen, H.J., (2003): Phosphatase activity and P fractions in soils of an 18- year-old Chinese fir (Cunninghamia lanceolata) plantation. Forest Ecology and Management, 178, 301-310.

Chen, S., Subler, S. and Edwards, C. A. (2002) Effects of agricultural biostimulants on soil microbial activity and nitrogen dynamics. Applied Ecology, 19, 249-59.

Fierer, N., Schimel, J., and Holden, P., (2003) Influence of drying-rewetting frequency on soil bacterial community structure. Microbial Ecology 45, 63-71.

Goldstein, A.H., Baertlein, D.A.S. and McDaniel, R.G. (1988) Phosphatate 
starvation inducible metabolism in Lycopersicum esculentum. Part I. Excretion of acid phosphatase by tomato plants and suspension-cultured cells. Plant Physiology, 87, 711-715.

Goransson, H., Godbold, D.L., Jones, D.L., Rousk, J., (2012). Bacterial growth and respiration responses upon rewetting dry forest soils: impact of drought-legacy. Soil Biology and Biochemistry 57, 477486.

Hueso, S., García, C., Hernandez, T., (2012) Severe drought conditions modify the microbial community structure, size and activity in amended and unamended soils. Soil Biology and Biochemistry 50, 167173.

Hueso, S., Hernandez, T., García, C., (2011) Resistance and resilience of the soil microbial biomass to severe drought in semiarid soils: the importance of organic amendments. Applied Soil Ecology 50, 27-36.

Kiss S, Dragan-Bularda, M and Radulescu D. (1975) Biological significance of soil enzymes accumulated in soil. Adv. Agron. 27, 25-87.

Meisner, A., Baath, E., Rousk, E., (2013) Microbial growth responses upon rewetting soil dried for four days or one year. Soil Biology and Biochemistry 66, 188-192.

Moreno, J. L., Bastida, F., Ondoño, S., García, C., Andrés-Abellán, M., López-Serrano, F. R. (2017): Agro-forestry management of Paulownia plantations and their impact on soil biological quality: The effects of fertilization and irrigation treatments. Applied Soil Ecology 117-118, 46-56.
Placella, S., Brodie, E.L., Firestone, M.K., (2012) Rainfall-induced carbon dioxide pulses result from sequential resuscitation of phylogenetically clustered microbial groups. Proceedings of the National Academy of Sciences of the United States of America 109, 10931-10936.

Reysek, K., Formanek, P. and Pavelke, M. (2008) Estimation of protease activity in soil at low temperatures by casein amendment with substitution of buffer by demineralised water. Amino Acids, 35, 411- 417.

Roldan, A., Salinas-García, J. R., Alguacil, M. M., Díaz, E. and Caravacaa, F. (2005) Soil enzyme activities suggest advantages of conservation tillage practices in sorghum cultivation under subtropical conditions. Geoderma, 129, 178-185.

Schnitzer, M. (1991) Soil Organic matter. The next 75years, Soil Science, 151: 41

Sinsabaugh, R.L. (1994) Enzymic analysis of microbial pattern and process. Biology and Fertility of Soils, 17, 69-74.

Sinsabaugh, R.L., Antibus, R.K., Linkins, A.E. and McClaugherty, C.A. (1994) Wood decomposition: nitrogen and phosphorus dynamics in relation to extracellular enzyme activity. Ecology, 74, 1586-1593.

Skujins, J. (1967) Enzymes in soi 1. In "Soi 1 Hiochemistryfl (A.D. McLaren anti G.H. Petersons ed.) pp.371-klk. Marcel Dekker, New York.

Tabatabai, M. A. and Bremner, J. M. (1969) Use of p-nitrophenyl phosphate for assay of soil phosphatise activity. Soil Biology and Biochemistry, 1, 301-307.

\section{How to cite this article:}

Vimal Kumar, Priyankar Raha and Shankar Ram. 2018. Effect of Irrigation Schedule and Amino Acids Biostimulants on Soil Enzyme Activities in Potato (Solanum tuberosum L.) Crop. Int.J.Curr.Microbiol.App.Sci. 7(04): 1912-1920. doi: https://doi.org/10.20546/ijcmas.2018.704.219 